DOI: $10.5937 /$ kom $1603019 B$

Original scientific paper

\title{
STANDARDS OF ISLAMITY in Islamic Civilization
}

\author{
Habibollah Babaei \\ Department of Islam and West Studies \\ Islamic Science and Culture Academy, Qom, I. R. Iran
}

\begin{abstract}
What is the criterion for Islamity in Islamic civilization theory? Is it faith (internal feature) or Islam (external aspect)? Emphasizing Islam as an external issue could result in hypocrisy, and highlighting faith (iman) might lead to excommunication (takfir) from the civilization. In order to respond to this question, I will argue that Islamic civilization (in both theory and practice) starts from minimum Islam to include majority of people as Muslim Ummah, then it develops by faith-training to reduce hypocrisy. Faith-based civilization could be the peak point of Islamic civilization but faith per se (without external signs) cannot be evaluated on individual and social scale. Based on this, and contrary to excommunicators, Islam is the single way for recognition of religiosity and Islamity in the civilization. And iman is the way for a rapid and successful development of humanity, morality, and rationality with the aim of creating the greatest humanized communication system that is the hard core of every civilization.
\end{abstract}

Keywords: Islam, Islamity, criterion, Islamic civilization, iman, brotherhood, excommunication

\section{Introduction}

What is the criterion for Islamity in Islamic civilization? Does Islamic identity of civilization arise from the faith (iman) or practice (Islam)? Should the practice and external behaviours be deemed as a measure, this may lead to hypocrisy and insincerity in civilization. Converesly, if faith and internal factors are seen as standards for Islamic identity that could result

Corresponding author: habz109@gmail.com 
in excommunication and takfir. By considering exterior aspects of Islam as a key standard of Islamic civilization, the Muslim society will be very large in quantity and maybe very poor in quality. In contrast, by regarding faith (iman) as a major measure for Islamity and Islamization, Muslim civilization must expel many of its Muslim brothers from their own community (minimum quantity in extent of much quality). Now, which of the two is better for contemporary process and practice of civilization over Muslim world?

Needless to say, the duality such as this between faith and Islam does not mean that only one factor should be chosen and all the others rejected; rather it is to clarify the priority between Islam and iman. In other words, this is to classify iman and Islam in the foundation of civilization on the one hand, and in evaluation of Islamity on the other. Also, separating iman from Islam is to illuminate dialectic relationship between faith and practice. Moreover, by proposing this question about standards of Islamity I just want to draw a comparison between Islam and iman, and faith and practice, as two key factors in formation of Islamic civilization. Thus, this comparison is not to confine standards of Islamity in iman or Islam.

Also, it should be recalled that this article is not about the history of Islamic civilization in the past; it is about civilizational theories and practices nowadays, in Muslim communities such as Iran, Turkey, and Malaysia. All of them have identity problems in dialectic between Islam and Modernity on the one hand, and spiritual rationality and takfir on the other. In addition, this article is not a sociological piece of work; it is a theological approach in the name of theology of civilization which considers theology's influence on civilization.

However, the answer to the above questions is complicated, but of fundamental importance. In order to overcome this dilemma, it is essential to analyze the nature of civilization, and then, Islam must be considered in comparison to iman to find their respective influences on civilization.

\section{Nature of Civilization}

Civilization is the greatest system of inter-human communication that is based on humanity, morality, and justice. Civilization is the most complex and massive humanized communication system that has potency to expand to other nations and lands. This great social system has two functions, a negative and a positive one: the negative one is to reject and resist social evils, and the positive one is to provide great temporal and spiritual requirements. There are several components in the essence of civilization:

1. Civilization consists of a variety and diversity of religions, cultures, nations, and languages. The plurality and variety is essential for the 
construction of any civilization. The more constructive plurality and variety exist in the civilization, the greater perfection could be achieved (see: Babaei 2014: 97-112).

2. These variety and plurality require a comprehensive unit that should include all pieces to create a unique identity in civilization. This complexity and gigantic unit is not essentially on a geographical scale, rather its greatness could be on a small scale in which deep communication system exists. To make this clear, consider an extreme example of the small civilization in Carthage ${ }^{1}$ before Christ at the time of the Roman Empire.

3. Civilization is not hard and physical matter; it is a soft affair that occurs not between human and nature but between human and human. Thus, evaluation of the civilization must be done by human measures not by technological criteria. Based on this, I think the best term in the Qur'an for civilization is neither City (al-madina) $)^{2}$ nor land $(\text { al-balad })^{3}$, nor Kingdom $(\text { al-mulk })^{4}$, nor ability $(\text { at-tamakkun })^{5}$; it is Ummah ${ }^{6}$ that emphasizes Muslim system communication on a huge scale.

4. The nature of civilization arises from the classification and priority system of needs and values. In other words, the spirit of civilization depends

1 The city in Tunisia that was once the centre of the ancient Carthaginian civilization.

2 See following verses: "Certain women that were in the city said, The Governor's wife has been soliciting her page he smote her heart with love we see her in manifest error" (12:30), and "The people of the city came rejoicing" (15:67).

3 See following verses: "And when Abraham said, My Lord, make this land secure, and turn me and my sons away from serving idols" (14:35); "And the good land its vegetation comes forth by the leave of its lord and the corrupt (its herbage) it comes forth but scantily Even so We turn about the signs for a people that are thankful" (7: 58).

4 See following verses: "He said, My Lord, forgive me, and give me a kingdom such as may not befall anyone after me surely Thou art the All giver" (38: 35); "They follow what the Satans recited over Solomon's kingdom Solomon disbelieved not, but the Satans disbelieved" (2: 163).

5 See following verses: "Have they not regarded how We destroyed before them many a generation We established in the earth, as We never established you, and how We loosed heaven upon them in torrents, and made the rivers to flow beneath them? Then We destroyed them because of their sins, and raised up after them another generation" (6:6); "We had established them in that wherein We have not established you, and We appointed for them hearing, and sight, and hearts; and yet their hearing, their sight and their hearts availed them nothing, since they denied the Signs of God, and they were encompassed by that they mocked at" (46:26).

6 See following verses: "You are the best Ummah ever brought forth to men, bidding to honour, and forbidding dishonour, and believing in God Had the People of the Book believed, it were better for them some of them are believers, but the most of them are ungodly" (3: 110); "Surely this community of yours is one community, and I am your Lord; so serve Me" (21: 92). 
on the "margin and centre" system which brings forth the identity of civilization. For example the centre of Western civilization is money (Georg Simmel's theory) or science (Max Weber's viewpoint) so that other moral and cultural pieces must be recognized in the light of money or science.

Based on the above points I think civilization is not a univocal (al-mutavati') concept in the Logic terminology; civilization is an equivocal and hierarchical (al-mushakkak) concept. Thus, there could be several hierarchical civilizations, some of which are perfect and others incomplete.

Now the question arises here, what is the way to make a civilization with Islamic identity? Considering iman as a criterion for Islamity has serious potency for Takfir, whereas regarding Islam as a measure may result in hypocrisy. Both are destructive for human communication system. What is the solution to this paradox between hypocrisy and takfir in Islamic civilization? What is the way to do away with these two factors which can demolish human communication system?

In order to answer this question I will distinguish between iman and Islam on the one hand, and then I will survey their respective functions on civilization process on the other.

\section{Iman and Islam}

Iman and faith is a spiritual phenomenon that occurs in the heart. Contrary to Islam there is physical and ritual matter that appears in the body. Based on the Islamic viewpoint, iman includes Islam, but Islam does not essentially contain iman. Some Muslims are believers and someone is just a Muslim not mumin. Of course, there are some verses and narratives in the Islamic texts which declare Islam in comprehensive term including both physical and spiritual components. There are two meanings of Islam - Islam as a religion which contains both physical and spiritual sides, and Islam as a ritual and practice (Divani 2001: 130-133). The following narrative refers to the second meaning of Islam, which we concentrate on in this article:

Sama'ah says: I asked Imam Sadiq that does Islam differ from iman? He answered that iman always entails Islam, but Islam does not essentially require iman. I asked him again more explanation. Imam said: Islam is two testimonies (testifying Oneness of Allah and prophethood of the Prophet). By doing this testimony people's blood, marriage, and heritage will be protected, and all Muslims are equal in their Islam and in their superficial identity. But iman is spiritual conduction and genuine faith according to Islam (al-Hussaini al-Bahrani 1996: V/118). 
It should be noticed that based on some Muslim scholars' view there are many layers for Islam. For instance, there are differences between Islam before iman and Islam after it. Islam in the first step is very simple (saying just two words), and then this Islam starts to flourish in both physical and spiritual sides. Allamah Tabatabaei's view point about hierarchy of Islams refers to this kind of the blossoming of Islam, from an elementary stage into advanced levels. He says about these layers of Islam:

As men differ in degrees of their submission to Divine Decrees or legislations, so does their Islam. The first stage of Islam is to accept and obey the exoteric commandments, orders and prohibitions, by reciting al-shahadatayn, no matter whether the belief has entered into the heart or not. This Islam is followed by the first stage of al-iman (faith, belief); and that is the sincere belief in the above-mentioned shahadatayn,-such a believer faithfully obeys most of the rules of the shariah. This first stage of al-iman is followed by the second stage of Islam. It is the sincere acceptance of all true beliefs in detail, with its necessary concomitant, that is, good deeds - although occasional slips are not impossible. This Islam is followed by the second stage of al-iman; and it is the believing, with full details and reasoning, in the realities of the religion. This second stage of al-iman paves the way for the third stage of Islam. When the soul is sufficiently imbued with the above-mentioned Nan, and acquires its characteristics, then man's all animalistic and beastly faculties are subdued to the sublime powers of his intellect and spirituality. He keeps all his desires - pulling him to the material attractions and transient trinkets of this world - under firm control. Thereupon, he reaches a stage where he worships Allah as though he was seeing Him and if he was not seeing Allah, then Allah was seeing him. This Islam is followed by the third stage of al-iman. And then, the fourth stage of Islam follows the third stage of al-iman (see: Tabatabaei (1997): I/302-304).

When considering Islam, I mean the first layer (saying shahadah) from the four layers which are declared by Allamah Tabatabaei.

\section{The Criterion for Islam}

Civilization is a humanized communication system in this temporal world. Evaluation of this Spacio-temporal matter requires a tangible measure that is al-shariat. Al-shariat (Jurisprudence and ethical actions) affects human communication system on the surface, and then it influences human beings' heart as well. This internal effect provides additional support for social 
human communication. Moreover, Islam, even its impure and insincere version, has positive functions not only in making social safety and peace, but in making an opportunity for Muslims to practice iman and to decline their insincerity. Based on this, Islam is an absolutely vital aspect for Islamic civilization, even if it may result in hypocrisy. Hypocrisy (especially individual hypocrisy) is less dangerous than takfir. Takfir has a truly fundamental power to cause conflict and violence, while hypocrisy has no such destructive force.

Briefly, to cut hypocrisy and takfir, Muslims must recognize each other by minimum measures. The more measure for Islamization we propose, or the more benefits we provide for real Muslims, and also the more we inspect internal and spiritual issues over religious people, the more hypocrisy will appear in the society. At this point, hypocrisy could be the fruit of takfir. By takfir, human freedom will be restricted, and the freedom restriction usually generates hypocrisy. In other words, inquisition results in excommunication and excommunication causes threat and fear, and this fear paves the way for insincerity and dishonesty.

Furthermore, to cross from hypocrisy requires a faith-training system. In fact, the communicative function of Islam grows by faith and iman. Islam without iman has serious potency for hypocrisy which disturbs the human communication system. Yes, Islam per se may result in safety and peace, but it cannot result in spiritual training system that is the base of real human communication. To complete the communicating process, it is highly essential to make harmony between the outside and the inside in human community. Any paradox between heart and behaviour, or faith and practice, might conduce deep disruption in the social system. Based on this, in order to keep human communication it is necessary to start imanization (faith training process) immediately after Islamization.

Making iman in a society requires rationalization and justification of faith on the one hand, and creation of religious sensation and emotion on the other. This community is the faith-based one, but nobody evaluates other's faith and sincerity. This society is an optimistic society that recognizes many Muslims as Muslim. In such a world, no one should be deprived of their citizen rights for the little faith they have, just as nobody should receive any grants for their greater faith.

Accordingly, Islamity in Islamic civilization requires expanding of the realm of Muslim by considering Jurisprudent, not theological measures (by easiest and slightest criteria). Secondly, we should practice iman and faith in training system, without any evaluation of faith degree. By doing this it would be possible to keep hypocrisy and takfir out of Muslim community and to bring real rational and moral communication simultaneously. 


\section{Faith as a Foundation of Civilization (Iman and Imran)}

Although faith is not measure for Islamity, it is an ideal and foundation for Islamic civilization. Moreover, it is superior to Islam in the civilization process. There are several verses in the Qur'an that refer to the civilizational function of faith and iman on a social scale.

"Only he shall reconstruct God's Places of worship who believes in God and the Last Day, and performs the prayer, and pays the alms, and fears none but God alone it may be that those will be among the guided" (9: 18).

Even though this verse is about Mosque, but according to the terminology of mosque in Arabic language (al-masjid) it is wherever people worship God. Based on this, bazaar, university and battlefield in Islam contain the essence of the mosque. Thus, civilization in broad terminology could be called a mosque and its development can resulted from faith and iman.

The question arises here what is relative between civilization and faith to be foundation or ideal point of civilization? I think faith that exists in a person (individually) and people (socially) could have serious functions in the making of social humanized and ethical communications system.

To explain this point, I should refer to two kinds of self, one of which is individual and separate from others and the other is communal and integrated with others. Based on the view of Islamic theologians, every human has two selves; one of which must be controlled, and the other developed. According to Mutahhari's - a contemporary Iranian Muslim Theologian - there exists a formulation: a) a figurative-self that is unreal, from which egoism emerges; and b) a real-self by which human spirit blossoms. According to this perspective, the real-self, in contrast to the figurative-self, must be protected and promoted. Based on this categorization of the 'self', it can be understood why we, as Muslims, are advised to stand against the self, when Prophet Muhammad says: "put yourself as an enemy that you must fight him" (Majlisi 1983: LXVII/64), whilst at the same time, we are urged and recommended to know, respect, and honour the self (Mutahhari 2000: 223-224). ${ }^{1}$

1 It should be recalled that these two selves have been mentioned in the Qurān too when it states on the one hand: "Who forbade the soul its caprice" (79:41); "Surely the soul of man incites to evil" (12: 53), whereas on the other hand it also declares: "O believers, look after your own souls, He who is astray cannot hurt you, if you are rightly guided" (5: 105), "And when thy Lord said to the angels, See, I am creating a mortal of a clay of mud moulded. When I have shaped him, and breathed My spirit in him, fall you down, bowing before him!" (15: 28-29). Also see: 38: 71-72; 15: 28-29. 
The phrase "I not you" sprouts from the unreal self, and not from the real one that is mutual between $I$ and you. Therefore, by consideration of figurative-self that acts as a dividing wall between $I$ and you, I get myself as an isolated object from you. In contrast, by consideration of inclusive real self I will associate and empathize with others (ibid.: 223).

Mutahhari asserts that the figurative -self - the self that has been confined to the physical aspect of the self-cannot be in association with others. Conversely, the real-self is inclusive and related to others' (ibid.: 221-222). ${ }^{1}$

Now, I think iman and faith is very vital in real-self training and making deep communication between self and others. In fact, practicing rational faith strengthens and expands this real self and makes a bridge between $I$ and you. Formation of humanized communication requires this internal and spiritual process. Without this spiritual process, there will not be any guarantee to keep other's dignity and honour where the police system is off.

To support communal selves paves the way for great humanized communication system and civilizational brotherhood. Social and communal faith creates faith-based brotherhood that should be continuance of Islamic brotherhood. And Islamic brotherhood could be the continuation of human brotherhood. In human brotherhood we have minimum human commonalties, and in faith-based brotherhood maximum commonalties. In fact, the brotherhood starts from human brotherhood, then blossoms through Islamic brotherhood, and finally it gets completed by faith brotherhood (see: Babaei 2012: 7-24).

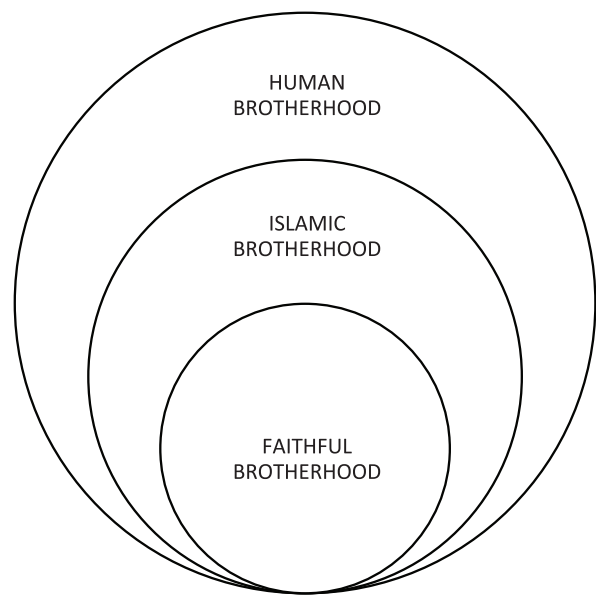

1 It should be recalled that in Mutahhari's view, distinction between real-self and figurative-self would be best foundation for perpetual good (that is rooted in real-self) and bad (that arises from figurative self) in ethics. 
Civilizational function of faith would be serious if we consider society and civilization as a real and independent being. Society, not as a complex and collection of individuals, but as a unique and autonomous being could own independent faith as well, which is rather stronger than individual faith. Based on this viewpoint, the role of faith in civilization and communication process does not only emerge from individual faith, but also it arises from social and great communal faith.

To sum up, although the measure for evaluation of Islamity is Islam not iman, Islam creates an average communication system on the surface. In order to make deep humanized communication it is crucial to consider individual and social faiths to bridge between self and others.

The problem here is unseen (al-ghayb) as a subject of the faith. Although we do not evaluate the degree of faith, how is it possible to bring faith and to avoid superstition in faith training system? It is a very tough question in religious civilizations to consider unseen (and myth) and rationality together.

\section{The "Unseen" (al-ghayb)}

According to the Qur'an, the Unseen is something that has happened, is happening or will happen; these occurrences are not seen or known by human beings except through divine revelation. Briefly, the unseen (al-ghayb) in the Qur'an is:

1) Hidden from human vision; ${ }^{1}$

2) Knowable and understandable ${ }^{2}$;

3) But not essentially useful for this world; ${ }^{3}$

1 "What has he observed the Unseen, or taken a covenant with the All-merciful?" (19: 81); "God has not taken to Himself any son, nor is there any god with Him; for then each god would have taken off that he created and some of them would have risen up over others; glory to be God, beyond that the describe, who has knowledge of the Unseen and the Visible; high exalted be He, above that they associate!" (23: 94-95).

2 "Mary, be obedient to the Lord, prostrating and bowing before Him" (3: 39). That is of the tidings of the Unseen, that We reveal to thee; for thou wast not with them, when were casting qulls which of them should have charge of Mary; thou wast not with them, when they were disputing. And "It was said, Noah get thee down in peace from Us, and blessing upon thee and on the nations of those with thee; and nations - We shall give them enjoyment, then there shall visit them from Us a painful chastisement" (11:50-51). That is of the tidings of the Unseen, that We reveal to thee; thou didst not know it, neither thy people, before this. So be patient; the issue ultimate is to the godfearing.

3 Imam Ali says about this: "There is something that God is quiet about that and did let us know. But His being quiet does not mean His forgetting" (Amili 2001: II/28) 
4) Known exclusively by God and the prophets ${ }^{1}$ or other people through divine revelation; ${ }^{2}$

5) Some of them do not interfere in the worldly affairs ${ }^{3}$;

6) Related to the believers: a) in the religious society, and b) in personal life, even in the secular society. Also it is related to wise people in a fully rational society, which can understand every essential unseen. ${ }^{4}$

Yet what is the way to distinguish between unseen (subject of faith) and superstition? I think interpretation (at-ta'vil) method in Islamic mystical exegesis could be one option to separate these two similar objects. This is the way to keep internal and external, natural and supernatural, and rational and mystical aspects of Islam simultaneously.

In fact, through an implicit word, we indicate the sort of "falling meaning" (nuzul al-ma'na) that involves reality in the present moment and, at the same time, includes other meanings as well. Put differently, all meanings of a word are common in their spirit ${ }^{5}$ but the understanding of the first layer of

1 "God will not leave the believers in the state in which you are, till He shall distinguish the corrupt from the good, and God will not inform you of the Unseen; but God chooses out of His Messengers whom He will. Believe you then in God and His Messengers; and if you believe and are godfearing, there shall be for you a mighty wage" (2: 174).

2 According to this reality we can say that the being "Unseen" is related to us and our limitation or capacity to know or to ignore (Tabatabaei 1997: VII/124).

3 "Say: 'I have no power to profit for myself, or hurt, but as God will. Had I knowledge of the Unseen I would have acquired much good, and evil would not have touched me. I am only a warner, and a bearer of good tidings, to a people believing"' (7: 186).

4 This will be occurred in the end of this world, "Eschatological" period, that every people can understand spiritual and supernatural matters easily even it seems firstly irrational or mythical. Imam Sadiq, the sixth Shi' ite leader, says that: "The knowledge is twenty seven letters. What has been discovered until now is just two letters not more. But Mahdi, the twelve Shi'it leader and the 'Messiah' of Muslims, brings another twenty two letters when he comes. He will spread out this letters among people and will add it to prior two letters. Finally the twenty seven letters will be done" (Majlisi 1983: LII/336).

5 There are some various ideas among some Islamic scholars about the nature of the spirit of meaning. The question is, what does "Hand" mean exactly when we use it in related to human beings as well as God, in terms of God's hand. In other words, what is the "hard core" of meaning over historical and time-bound context? In the third phrase, what is the major meaning that the word "Hand" sets up for it? There are three ideas among some Shiite Muslim scholars in response to this question: 1) Some scholars say that the meaning of "Hand", for instance, is the end, a goal or the reason of usage and attention to that thing. What do we mean when we talk about "Hand"? The spirit of the meaning of "Hand" is its function that makes us pay attention to "Hand", as an object, and use it. What is that? The reason that we notice "Hand", whether God's hand or a human being's hand, is that it is an "instrument or tool of work". In this usage of "Hand", there is no difference between God and human beings (see: Tabatabaei 1997: I/13). Every word here is a sign for the particular 
meanings is available for all people, while the higher meaning will be only possible to comprehend by those that attempt to understand it. Although, the higher meaning is beyond general mind, the lower meaning must be understandable and acceptable for all people.

The creation of words and the naming of objects have been accomplished mostly with a material end in view. Expressions have been created for those objects, states, and conditions which are material and available to the senses or near to the sensible world. As can be seen in those cases where the person addressed lacks one of the physical senses, if we wish to speak of matters which can be comprehended through the missing sense we employ a kind of allegory and similitude. For example, if we wish to describe light or colour to one who is born blind, or the pleasures of sex to a child that has not reached the age of adolescence, we seek to achieve our purpose through comparison and allegory and through providing appropriate examples. Therefore, if we accept the hypothesis that in the scale of Universal Existence there are immense levels of reality which are independent of the world of matter (and this is in reality the case), and that in each generation there are among mankind but a handful who have the capability of comprehending and having a vision of these realities, then questions pertaining to these higher worlds cannot be understood through common verbal expressions and modes of thought, they cannot be referred to except by allusion and through symbolism. Since religious realities are of this kind, the expression of the Qur'an in such matters must of necessity be symbolic (Tabatabaei 1979: 99-100).

Regarding this dilemma, Christian scholars proposed other way and solution. For instance, Bultmann explains the problem of myth in Christian context in the New Testament and Mythology:

result and function that we can achieve through that. As long as this result stays, the word as a sign of this meaning stays as well.2) And some other scholars focus on the concrete case or object (misdaq) of meaning (Khomeini 1993: 249-250). Khomeini agrees with the spirit of meaning. But he says that general human beings, laymen, cannot imagine the abstract meaning. Consequently, they usually confront the concrete objects. Therefore the objects and the examples of meaning, that everyone can see, have the main role in the construction of some particular meanings for some words. Khomeini says that the words are tools used for the objective cases. Those cases make you to find common point among them and put the word as a sign for that common point. 3) There are other scholars that insist on the unconscious meaning in the mind (al-irtikaz) that is present in the human mind through objects of concept. Put differently, the spirit of meaning appears through the several experiences that make us find some pure characters in similar cases. Then we set up a particular word for particular characters as a meaning or spirit of meaning. (Yazdanpanah 2003: 34). 
Can Christian proclamation today expect men and women to acknowledge the mythical world picture as true? To do so would be both pointless and impossible. It would be pointless because there is nothing specifically Christian about the mythical world picture, which is simply the world picture of a time now past that was not yet formed by scientific thinking. It would be impossible because no one can appropriate a world picture by sheer resolve, since it is already given with one's particular historical situation (Bultmann 1984: 1, 3).

Bultmann understands myth as a divine example, which is represented in worldly concepts. In other words, myth is language of "the beyond" or "kerygma" that is represented as a matter here and now, in the visible situation in order to become understandable for human beings. ${ }^{1}$ Through myth, man speaks about the other side (the beyond) in terms of comprehensible word to own. By using myth, man speaks of these other-worldly powers in the tangible terms of a world (Ashraf 1972: 50-51). For instance, the transcendence of God is phrased in terms of the time and the space; and the origin of this world is explained by describing the world as an egg or a tree; and by referring to the gods in terms of human life.

Mythology expresses a certain understanding of human existence. It believes that the world and human life have their ground and their limits in a power which is beyond all that we can calculate or control. Mythology speaks about this power inadequately and insufficiently because it speaks about it as if it were a worldly power. It speaks of gods who represent the power beyond the visible, comprehensible world. It speaks of gods as if they were men and of their actions as human actions, although it conceives of the gods as endowed with superhuman power and of their actions as incalculable, as capable of breaking the normal, ordinary order or events. It may be said that myths gave to the transcendent reality an immanent, this worldly objectivity. Myths give worldly objectivity to that which is unworldly (Bultmann 1984: 19).

Thus, every Biblical point that is not intelligible for human mind (as a "beyond" human thought) is gained by Bultmann as myth.

1 Bultmann adds: "God's Word is not a mystery to my understanding. On the contrary, I cannot truly believe in the Word without understanding it. But to understand does not mean to explain rationally. Then I understand them (love and friendship) in searching for them, in asking for them. In the same manner I can understand what God's grace means, asking for it as long as it does not come to me, accepting it thankfully when it does come to me" (Bultmann 1984: 43-44). 
Based on these points about myth and the Unseen, the question here is, how can we understand and believe the "Historical beyond", "Coming beyond", or other sort of the beyonds within the limited human life? In other words, how is it possible to move between human culture and the "beyond"? On the other hand, what is the problem, theologically or sociologically ${ }^{1}$, in the connection between this religious beyond and human civilization?

According to Bultmann, de-mythologizing is a method of interpretation (ibid.: 40, 42). His response to the question of this particular method is as follows: a) in the Existential view, human beings, on a universal scale, exist only through their free decision to "each now"; b) divine revelation appears in an existential situation with existential goals to develop human existence. In other words, the purpose of God's revelation, as God's action, is to foster and train this human and personal existence (ibid.); c) because the Bible is an existential phenomenon, it must be interpreted in an existential way. This existential way starts from the proposition point, through the existential question (ibid.: 46) "how is man's existence understood in the Bible?", and continues through interpretation of existential de-mythologizing that makes clear the true meaning of God's mystery; d) "if it is true that the right questions are concerned with the possibilities of understanding human existence, then it is necessary to discover the adequate conceptions by which such understanding is to be expressed. To discover these conceptions is the task of philosophy"2. Thus, we should learn from existentialist philosophy, because in this philosophical school human existence is a direct object of attention (ibid.: 55); e) without the decision, "you must exist", without the readiness to be a human being, a person who in responsibility takes it upon himself to be, no one can understand a single word of the Bible. Thus only then does it become clear that the hearing of the word of the Bible can take place exclusively in the personal decision (ibid.: 57); f) the existential interpretation does not mean rationalization, theorization and analysis of the Bible. ${ }^{3}$ But rather, it is a sort of faith (existential way) that makes a reader be

1 In term of Berger's ideas some sociological problems appear in the relationship between religion that involves mythical points and human culture. The major dilemmas that Berger lists are 1) Legitimation 2) Theodicy, and 3) Alienation. (see: Berger 1967: 32-90)

2 Bultmann responds to this objection that this kind of interpretation leads to reductionism of religion to philosophy: "But now the objection is brought forward that exegesis falls under the control of philosophy. This is the case indeed, but we must ask in what sense it is so. It is an illusion to hold any exegesis can be independent of secular conception. Every interpreter is inescapably dependent on conceptions which he has in herited from a tradition, consciously or unconsciously, and every tradition is dependent on some philosophy or other" (Ibid.: 54-55).

3 "Christian preaching is kerygma, that is, a proclamation addressed not to the theoretical reason, but to the hearer as a self. De-mythologizing will make clear this function of preaching as a personal message" (Bultmann 1984: 38-39). 
ready to connect with existential text (ibid.: 61-65). "I can understand what God's grace means, asking for it as long as it does not come to me, accepting it thankfully when it does come to me" (ibid.: 44); and g) the Existential de-mythologizing interprets the Scripture, asking for existential and deeper meaning and freeing Word of God from a by-gone world-view (ibid.: 35-36, 43). In this way, it will have a historical message, "here" and "now".

In spite of these crucial points in Bultmann's project, his project is not ready, yet, to fill gaps between faith and culture. If a belief is not reasonable and cannot be discussed, then how can we distinguish between an existential belief and a non-existential one? What is the measure between a biblical belief and an unbiblical one? Does not this belief lead to "emotionalism" and finally "fundamentalism"? What is the difference between rational beliefs and irrational ones? Conversely, does existential individualism which implies plurality, dispersal and sprawl, intensify a religious otherness and religious violence? In addition, de-mythologizing in Bultmann's thought is de-secularization or de-historization. Then, what is the result of this existential de-mythologizing? It seems that Bultmann confirms the secular doctrine by this separation between belief and rationality. In fact, he does the secularization in his theology when he focuses only on the belief. It is curious when Bultmann focuses on the belief but ignores its mythical aspect.

\section{Interpretation}

Firstly, it should be considered that in Tabatabaei's view, God's religions have been sent to resolve basic human disputes (according to "Islamic theology of religions") in human society (see: Tabatabaei 1997: II/111-134). ${ }^{2}$ It is because of the impossibility of actualization of religions and divine identity without ethical conditions, as well as the impossibility to create ethical condition without safe and proper society.

1 "The task of de-mythologizing received its first impulse from the conflict between the mythological views of the world contained in the Bible and the modern views of the world which are influenced by scientific thinking, it has become evident that faith itself demands to be freed from any world-view produced by man's thought, whether mythological or scientific. De-mythologizing is the radical application of the doctrine of justification by faith to the sphere of knowledge and thought. Therefore, our relation to the world as believers is paradoxical" (Bultmann 1984: 85).

2 "The people were one nation; then God sent forth the Prophets, good tidings to bear and warning, and $\mathrm{He}$ sent down with them the Book with the truth, that $\mathrm{He}$ might decide between the people touching their differences; and only those who had been given it were at variance upon it, after the clear signs had come to them, being insolent one to another; then God guided those who believed to the truth, touching which they were at variance, be His leave; and God guides whomsoever He will to a straight path" (2:213). 
On the other hand, religions have "come down" (nuzul in Qur'anic term) for human beings. This coming down to the human area is not just for the obedience, but rather it is for knowing and understanding, too. Therefore, the explanation of the Qur'an or the Bible should be understandable and acceptable by human beings. The religions come down to be intelligible and justifiable, and then, to help people to improve their social and individual situation. In other words, religion is not for confirming the human world, but rather, it is in reality to change and improve it. Then, because of the different audiences, the Qur'an must be translated and interpreted in different forms. Moreover, several layers of meaning in the Qur'an require various interpretation of the Qur'an according to each layer meaning.

The means by which God sends down His message into human life is the "physical-life language". In other words, God sends His high message through the human mindset and human language, in a cultural way, to make it intelligible and easier to understand and believe. It seems that there is not another way to make this supernatural essence (here the "Unseen") intelligible for human thought (ibid: III/70). Otherwise, the Qur'an would be merely a local message for a particular people in a particular condition. This is the meaning of the Prophet Mohammad's saying that: "we the prophets are ordered to talk to people [cultures, civilizations, and various nations] according to their intellects [and their capacity]" (Majlisi 1983: III/85). ${ }^{1}$ And God says in the Qur'an:

He sends down out of heaven water, and the wadis flow each in its measure, and the torrent carries a swelling scum; and out of that over which they kindle fire, being desirous of ornament or ware, out of that rises a scum the like of it. So God strikes both the true and the false. As for the scum, it vanishes as jetsam. Even so God strikes His similitudes (13: 17).

Tabatabei explains this verse in his way that God's message, like raining, is one (water) but situations and measures are very different. He says in the interpretation of this verse that divine knowledge is like water which God sends down, without any limitation in the quantity and quality. Then, this knowledge like water flows according to measures among human beings. There are some time-bond laws (al-mansukh) like scum (in this example) that passes away as a worthless thing. Yet, the divine truths that are limited in the words and sentences and implications are stable within God's purpose through these words and particles. (see: Tabatabaei 1997: III/71 - 72; 1981: 10).

1 This is for the theological basis that God's guidance is not limited to one and not another. That is a general message for all human beings in spite of their different capacities and various situations (see: Kashani 1980: I/32, Jami 1990: 134). 
However, different audiences and various levels of meaning do not involve pluralistic and fragmented meanings. The essence of a message is unique but assumes a different shape (ontologically) and different language (epistemologically). Differences in the shape and frame do not change the essence or the hard core of the message. This is because of: a) the unity of human nature; b) the unity and stability of divine messages; and c) the unity of history as the context of humanity and of the divine message.

Based on this, the lowest layer of the meanings about unseen is understandable for all, even for non-believers. This level of the unseen is discussable and arguable for all Muslims and non-Muslims. So, it would be the way to distinguish between Unseen and superstition.

\section{Conclusion}

I have emphasized humanized communication system in two minimum and maximum levels for Islamic civilization. The minimum layer of Islamic civilization is based on the external aspects of Islam. And the Islamization of the civilization must be evaluated according to these jurisprudent and ethical measures. But the advanced level of Islamic civilization must go to a deep layer of civilization in which internal faith creates a new deep communication system. However, insisting on internal matters in Islamic civilization does not require ignorance from external aspects of Islam as a major criterion for Islamity in civilization. Islam is always important for evaluation of Islamity in the civilization. Although Muslims insist on Islamic aspects of civilization and minimum measures to build maximum Ummah, civilization needs iman to complete the civilizational process and great humanized communication organism. Also, focusing on internal facets of Islam in Islamic civilization does not mean superstition. By considering rational levels of faith-subjects, superstition problem could be avoided and controlled in the Islamic civilization and communication based on faith and spirituality.

Civilization that is based on Islam (before iman) differs widely from the one based on Islam (after iman). Islam before iman is elementary Islam with less civilizational function, which involves potency for hypocrisy, but Islam after iman is more comprehensive than earlier. In the light of iman, Islam will be performed comprehensively by Muslims, even when they are alone. Just as Islam effects internal aspects of life, so too iman effects external facets. In other words, by deep faith to Islamic teachings Muslims will practice Islam widely even in individual fields and private life. But civilization based on Islam (before iman) will stop at the superficial layer. This imperfect Islam will lead to fragmented Islam that is not Islam, it is a cartoon of Islam which is rejected by the Qur'an, when it says: 
"Yet you murdered each other and forced a number of your people out of their homeland, helping each other to commit sin and to be hostile to one another. When you had expelled people from their homeland and later they had been made captives (of other people), you then paid their ransom (thinking that it was a righteous deed). God forbade you to expel these people in the first place. Do you believe in one part of the Book and not in the other? Those who behave in this way shall reap disgrace in this world and severe punishment on the Day of Resurrection. God is not unaware of things that you do" (2: 85).

Received: September $16^{\text {th }}, 2016$

Accepted: October $20^{\text {th }}, 2016$

\section{References}

Qur'an.

Al-Hussaini al-Bahrani, Sayyid Hashim (1996), Al-Burhan fi Tafsir al-Qur'an, Qom, Qism al-dirasat al-Islamiyyah, Muassasah al-Bisah.

Amili, Shaykh Hurr (2001), Vasail al-shiah, Qom, Manshurat Dar al-hikmah.

Ashraf, Morris (1972), Rudolf Bultmann, Texas, Word Books Publisher.

Babaei, Habibollah (2012), "Okhowwate ensani va Peyamadhaye an dar arseye jahani”, in: Isra 5 (1): 7-24.

Babaei, Habibollah (2014), "One and Many in Islam, the Path and the Ways in the Qur'an”, in: Kom: Journal of Religious Sciences 3 (1): 97-112.

Berger, Peter. L (1967), The sacred Canopy, Elements of a Sociological Theory of Religion, New York, Anchor Books.

Bultmann, Rudolf (1984), New Testament and Mythology and Other Basic Writings, Philadelphia, Fortress Press.

Divani, Amir (2001), Daneshname-ye Imam Ali, Edited by Ali Akbar Rashad, Tehran: Academy of Islamic Culture and Thought.

Jami, Abd al-Rahman (1990), Nagd al-nusus, Tehran, Moassese-ye Motaleat va Tahgigate Farhangei, 1990.

Kashani, Feyz (1980), Tafsir as-Safi, Beirut, Muassasah al-A'lami.

Khomeini, Ruhollah (1993), Adab al-Salat, Tehran, Moassese-ye Tanzim Va Nashre Asare Emam Khomeini.

Majlisi, Muhammad Bāqir (1983), Bihar al-anvar, Beirut, Muassasa al-Vafa.

Mutahhari, Murtazā (2000), Ta’lim va Tarbiat dar Eslam, Tehran, Sadrā. 
Tabatabaei, Muhammad Hussain (1979), Shia in Islam, Translated by Seyyed Hossein Nasr, New York, State University of New York Press.

Tabatabaei, Muhammad Hussain (1981), Risalat al-vilayah, Qom, Muassatu Ahl al-bayt.

Tabatabaei, Muhammad Hussain (1997), Al-Mizan fi Tafsir al-Qur'an, Beirut, Muassasah al-A'lami li al-Matbuat.

Yazdanpanah, Yadollah (2003), Interpretation of the Khomeinis view, Qom, The Conference of Imam Khomeini. 